\title{
Chemical Profile and Cytotoxic Activity of Leaf Extracts from Senna spp. from Northeast of Brazil
}

\author{
Juliana G. A. Silva, ${ }^{a}$ Alexander A. Silva, ${ }^{b}$ Isabel D. Coutinho, ${ }^{b}$ Claudia O. Pessoa, ${ }^{c}$ \\ Alberto J. Cavalheiro ${ }^{b}$ and Maria G. V. Silva*a \\ ${ }^{a}$ Departamento de Química Orgânica e Inorgânica and ${ }^{c}$ Departamento de Fisiologia e \\ Farmacologia, Universidade Federal do Ceará, 60440-900 Fortaleza-CE, Brazil \\ ${ }^{b}$ Instituto de Química, Universidade Estadual de São Paulo, 14800-060 Araraquara-SP, Brazil
}

\begin{abstract}
Methanolic, diethyl ether and $n$-hexane extracts of leaves of four species of Senna (S. gardneri, S. macranthera, $S$. splendida and $S$. trachypus) were analyzed by gas chromatography coupled to mass spectrometry (GC-MS). Using linear retention indices and mass spectral data, 34 compounds were identified, including fatty acids, flavonoids, terpenoids and steroids that were not reported previously for these species. Additionally, the cytotoxicity of the extracts against different tumor cell lines was determined. The cytotoxicity was then correlated with the chemical composition of the extracts by partial least squares-discriminant analysis (PLS-DA). The $n$-hexane extract of $S$. gardneri and the ethyl ether extract of $S$. splendida were the most active against human colon ( 59.75 and $31.37 \%$, respectively) and human glioblastoma ( 52.85 and $48.28 \%$, respectively) cell lines.
\end{abstract}

Keywords: Senna spp., GC-MS, dereplication, cytotoxicity, multivariate analysis

\section{Introduction}

The genus Senna (Leguminoseae) contains approximately 260 species found in tropical and subtropical regions worldwide and is widely distributed in northeastern, southeastern and southern Brazil. ${ }^{1-3}$ Senna species are also reported in India, Australia and Africa. ${ }^{4}$ The genus is within the tribe Cassieae Bronn and subtribe Cassinae Irwin \& Barneby, which also include the genera Cassia L. and Chamaecrista Moench. The species of Senna and Chamaecrista were included in the genus Cassia before the taxonomic revision of Irwin and Barneby, 1981. ${ }^{5}$

Senna species produce flavonoids, polysaccharides, steroids, chromones, lactones and triterpenes but the most common classes of secondary metabolites are anthraquinones and piperidine alkaloids. ${ }^{6-8}$ Based on literature reports, the leaves of Senna species have a variety of pharmacological activities. The laxative propriety of anthrone rhein is well known, which is obtained as sennosides primarily from Cassia acutifolia and C. angustifolia and is metabolized by bacteria from the intestinal tract of humans. ${ }^{9} n$-Hexane and methanol extracts of the leaves of S. macranthera have strong laxative activity,

*e-mail: mgvsilva@ufc.br comparable with that of the positive control bisacodyl, and anti-inflammatory activity, similar to that of diclofenac sodium. ${ }^{10}$

The dimeric indole alkaloid cassiaindoline in the leaves of $S$. alata has significant analgesic and anti-inflammatory activities, and the anthraquinones in the leaves of this species has effective antifungal and bactericidal activities. ${ }^{11}$ Lipophilic extracts and anthraquinones obtained from seeds of $C$. tora inhibit EBV-EA activation induced by teleocidin B-4, which may indicate a chemopreventive action. ${ }^{12}$ Extracts and the alkaloids cassine and spectaline of $S$. spectabilis have no cytotoxic effect on murine macrophages (J774 cell line), ${ }^{8}$ and the extract of S. sophera is not cytotoxicity. ${ }^{13}$

Barakol, an anxiolytic agent isolated by acid hydrolysis of S. siamea leaves, is toxic to P19 cells and induces apoptosis, ${ }^{14}$ but the ethanolic and aqueous extracts of leaves from C. siamea (syn. S. siamea) were not cytotoxic to KB and Vero cells. ${ }^{15}$ Esakkirajan et al. ${ }^{16}$ obtained spiro[piperidine-4,2' (1' $H$ )-quinazolin]-4' (3' $H)$-one from the leaves of $C$. auriculata with an half maximal inhibitory concentration $\left(\mathrm{IC}_{50}\right.$ ) value of $25 \mu \mathrm{g} \mathrm{mL}^{-1}$ for human colon cancer cell line HCT15.

The techniques used classically to isolate and identify natural compounds from plants are frequently criticized 
because of the long chromatographic process required, the waste of organic solvents, and often, the isolation of well-known compounds in various species. ${ }^{17}$ Therefore, to avoid the re-isolation of known compounds, qualitative analysis on hyphenated systems (dereplication) has a fundamental role in the analysis of metabolic profiles of the most diverse species of plants. ${ }^{18,19}$ Additionally, the comparisons of chemical profiles of extracts with different biological activities can be used to indicate hit compounds related to the observed activity. Then, to correlate chemical compounds and biological activity, data can be analyzed by multivariate statistics; typically combining supervised techniques like principal component analysis (PCA) or hierarchical cluster analysis (HCA), and unsupervised techniques, partial least squares (PLS) and related regression techniques. ${ }^{20,21}$

Based on these considerations and the positive and negative results previously reported for the cytotoxicity of extracts from Senna and Cassia species, 12 extracts from the leaves of four species of Senna (S. gardneri, S. macranthera, S. splendida and S. trachypus) were evaluated for cytotoxic effects on three human cancer cell lines, i.e., OVCAR-8, HCT-116, and SF-295. The chemical profiles of the extracts obtained by gas chromatography coupled to mass spectrometry (GC-MS) were then compared to identify active compounds.

\section{Experimental}

Plant material

The leaves of S. gardneri, S. macranthera, S. splendida and $S$. trachypus were collected in Chapada Ibiapaba, Ceará, Brazil, between August 2010 and March 2012. Plants were identified by Prof Edson de Paula Nunes, Departamento de Biologia of Universidade Federal do Ceará (UFC), and the samples were registered as numbers 47.385, 47.384, 47.387 and 47.377, respectively, and stored in the Herbarium Prisco Bezerra at UFC. After drying at room temperature (ca. $25^{\circ} \mathrm{C}$ ), $3.0 \mathrm{~g}$ of leaves from each species of Senna was extracted with $40 \mathrm{~mL}$ of organic solvents ( $n$-hexane, diethyl ether and methanol, consecutively) for $12 \mathrm{~min}$ in an ultrasound bath. The extracts were filtered and then concentrated under vacuum on a rotary evaporator.

\section{Reagents and equipment}

The homologous series of $\mathrm{C}_{12}-\mathrm{C}_{40}$ alkanes, pyridin, MSTFA ( $N$-trimethylsilyl- $N$-methyl trifluoroacetamide) and methoxyamine hydrochloride were purchased from Sigma Chemical Co. (St. Louis, MO, USA). All other chemicals were analytical grade and were purchased from Merck (Darmstadt, Germany). All solvents used for GC-MS analyses were analytical grade. Methanol, $n$-hexane and diethyl ether were purchased from Tedia (Fairfield, USA). The samples were analyzed on a Shimadzu GC-MS QP2010 (Tokyo, Japan) equipped with an automatic sampler AOC-20Si using an ionization source of $70 \mathrm{eV}$ and fragmentation by electron ionization (EI), GC-MS Solutions software version 1.02 (Tokyo, Japan) and a fused silica capillary column SULPECO DB-5 (5\% phenyl-methylpolysiloxane, $30 \mathrm{~m} \times 0.25 \mathrm{~mm} \times 0.25 \mu \mathrm{m})$. For statistical analyses, HCA and PLS-DA were performed using Matlab 7.12.0 (MathWorks, Natick, MA, USA) and PLS_Toolbox (Eigenvector Research, Wenatche, USA), respectively.

\section{Extract derivatization}

After drying at room temperature (ca. $25^{\circ} \mathrm{C}$ ), $3.0 \mathrm{~g}$ of leaves from each species of Senna was extracted with $40 \mathrm{~mL}$ of solvents ( $n$-hexane, diethyl ether and methanol, consecutively) for $12 \mathrm{~min}$ in a sonicator. The extracts were filtered and then concentrated under vacuum. All extracts were treated with the trimethylsilylation reaction. The methanolic extracts were subjected to methoxymation with modifications. ${ }^{22}$ Extracts (20 mg each) were added to vials and dissolved in $300 \mu \mathrm{L}$ of pyridine. Shortly thereafter, $100 \mu \mathrm{L}$ of methoxyamine hydrochloride $\left(20 \mathrm{mg} \mathrm{mL}^{-1}\right)$ was added to the vials and the derivatization was performed at $30{ }^{\circ} \mathrm{C}$ for $90 \mathrm{~min}$. Following derivatization, $150 \mu \mathrm{L}$ of MSTFA was added and the final solution was placed in a water bath at $37{ }^{\circ} \mathrm{C}$ for $30 \mathrm{~min}$. The $n$-hexane and ethyl ether extracts $(20 \mathrm{mg})$ were dissolved in $300 \mu \mathrm{L}$ of pyridine. Subsequently, $150 \mu \mathrm{L}$ of MSTFA was added and the above procedure was repeated. After termination of the reaction, the samples were filtered through membranes (Chromafil ${ }^{\circledR}$ Xtra RC-20/25, with $0.20 \mu \mathrm{m}$ pores) and stored in $2 \mathrm{~mL}$ vials for $24 \mathrm{~h}$ at $4{ }^{\circ} \mathrm{C}$ before GC-MS analysis.

Gas chromatography coupled to mass spectrometry analyses (GC-MS) of Senna spp. extracts and identification of compounds

The samples were analyzed by GC-MS with injector temperature was adjusted to $260{ }^{\circ} \mathrm{C}$. Helium $\left(1 \mathrm{~mL} \mathrm{~min}^{-1}\right)$ was the carrier gas and injections of $1 \mu \mathrm{L}$ occurred in split mode $(1: 10)$. The oven temperature was kept at $120{ }^{\circ} \mathrm{C}$ for $3 \mathrm{~min}$ and then programmed to $320{ }^{\circ} \mathrm{C}$ at $3{ }^{\circ} \mathrm{C} \mathrm{min}{ }^{-1}$. The mass spectrometer operated in EI mode $(70 \mathrm{eV})$ and the acquisition range was $\mathrm{m} / \mathrm{z}, 40-660$. The total time of the analysis was $79.67 \mathrm{~min}$. The trimethylsilane (TMS) 
derivatives were identified by comparison of their mass spectra with those in National Institute of Standards and Technology (NIST) or Wiley libraries and Golm Metabolome Database (GMD), requiring at least 90\% similarity and experimental linear retention indices (RI) within literature RI values \pm 10 .

\section{3-(4,5-Dimethylthiazol-2-yl)-2,5-diphenyltetrazolium bromide (MTT) assay for cell viability}

Tumor cell lines OVCAR-8 (ovarian carcinoma), HCT-116 (human colon) and SF-295 (human glioblastoma) were provided by the National Cancer Institute (USA). The extracts from the leaves of Senna species were diluted in dimethyl sulfoxide (DMSO) at a concentration of $125 \mathrm{mg} \mathrm{mL}^{-1}$ and then plated. The cells were added shortly thereafter and were plated at concentrations of $0.1 \times 10^{6}$ cells mL $\mathrm{m}^{-1}$ for OVCAR- 8 and $0.7 \times 10^{5} \mathrm{cells} \mathrm{mL}^{-1}$ for HCT-116 and SF-295 lineages. The cells were incubated with the extracts for $72 \mathrm{~h}$ in an incubator at $5 \% \mathrm{CO}_{2}$ at $37^{\circ} \mathrm{C}$. Following treatment, cells were washed and fresh medium was prepared. The MTT dye solution $(150 \mu \mathrm{L})$ was added to each well for $3 \mathrm{~h}$. The absorbance was measured after dissolving the precipitate with $150 \mu \mathrm{L}$ of pure DMSO on a plate spectrophotometer at $595 \mathrm{~nm} \cdot{ }^{23}$ Doxorubicin was purchased from Sigma Aldrich (San Diego, USA) and was used as the positive control. Experiments were repeated independently three times. The results are expressed as percentage of cell viability.

\section{Statistical analyses}

HCA was used for an initial, exploratory analysis of the cytotoxicity data for the 12 extracts on the three tumor cell line lineages $(12 \times 3)$, using preprocessing mean center data and distance to k-nearest neighbor. Then, partial least squares-discriminant analysis (PLS-DA) was used to model the three clusters obtained in the HCA. The data set (12 samples and 110 compound areas) was normalized, and five latent variables were selected to build the model.

\section{Results and Discussion}

The extracts obtained by sonication with $n$-hexane, diethyl ether and methanol from the leaves of $S$. gardneri, $S$. macranthera, S. splendida and S. trachypus were submitted to silylation and further analyzed by GC-MS to obtain linear retention indices (RIs) and mass spectra of the compounds, which were compared with the mass spectra in three mass spectra (MS) libraries (i.e., NIST, GMD and Wiley). The RIs were calculated from the retention times obtained from the chromatograms of each compound and of a standard mixture of alkanes $\left(\mathrm{C}_{12}-\mathrm{C}_{40}\right)$, according to Van den Dool and Kratz equation. ${ }^{24}$ From the extracts of the four species obtained with the three different solvents, 34 compounds were identified, including carboxylic acids, fatty acids, fatty alcohols, long-chain alkanes, diterpenes, triterpenes and sterols, in addition to the flavonoids chrysin and quercetin. The compounds identified by GC-MS in the extracts of Senna species are presented in Table 1.

Each extract was prepared and analyzed in triplicate. With the extracts obtained with the different solvents, the metabolite diversity of the samples was demonstrated. As expected, the more polar extracts obtained with methanol contained high levels of mono-, disaccharides and polyols, whereas the $n$-hexane extracts were rich in terpenoids and fatty acids and other lipophilic compounds. However, the extracts obtained with diethyl ether were less complex. The compounds identified in the GC-MS chemical profiles are shown in Figure 1, and three representative GC-MS chromatograms are shown in Figure 2.

A multivariate analysis using HCA and PLS-DA was conducted of the chemical composition and the cytotoxicity of the extracts against human tumor cells to identify the compounds potentially correlated with this activity. The results of the cytotoxicity assays are shown in Table 2 .

The $n$-hexane extract of $S$. gardneri had the highest activity against HTC-116 and SF-295 cancer cell lines with cell growth inhibited by 59.75 and $52.85 \%$, respectively, whereas the highest inhibition of OVCAR- 8 cells occurred with the methanol extract of $S$. macranthera. Although the cytotoxicity of plant extracts was generally weak ( $<75 \%$ inhibition), the cytotoxic potential of these extracts was significantly different. In addition to differences in cytotoxicity, the chemical composition of these extracts was also very different; therefore, we used multivariate analysis of the two data sets (i.e., cytotoxicity and chemical composition) to identify the compounds likely responsible for the biological activity. Thus, the 12 extracts were initially analyzed by HCA, and using cytotoxicity as the dependent variable, the samples were classified into three clusters: (A) the extracts of $\mathrm{SgH}$ and $\mathrm{SsE}$ with the most activity on HTC-116 and SF-295 cells; (B) the extracts of StM and SmM with the most activity on OVCAR-8 cells; and (C) the extracts with low or no cytotoxicity (Figure 3).

The classification obtained by HCA was then used in a supervised analysis (PLS-DA) to establish a relationship between the extract's cytotoxicity and specific chemical constituents (variables). The PLS-DA was performed using a matrix with 12 cases (extracts) and the areas of chromatographic peaks $(12 \times 110)$. The model generated from five latent variables (LV) explained $83.6 \%$ of the 
Table 1. Compounds and respective peak areas found in the extracts from leaves of Senna spp. as trimethylsilyl derivatives in GC-MS analyses

\begin{tabular}{|c|c|c|c|c|c|c|c|}
\hline Compound & $\mathrm{Rt}^{\mathrm{a}} / \min$ & $\mathrm{RI}_{\exp }{ }^{\mathrm{b}}$ & $\mathrm{RI}_{\mathrm{lit}}{ }^{\mathrm{c}}$ & $\mathrm{MS}^{\mathrm{d}} / \%$ & Compound name & Representative ions $(\mathrm{m} / \mathrm{z})^{\mathrm{e}}$ & Senna spp. extract ${ }^{\mathrm{f}}$ \\
\hline 1 & 6.080 & 1301 & 1289 & 97 & succinic acid* & $147(\mathrm{BP})^{\mathrm{g}}, 73,247$ & SgM, StM, SsE, SsM, SmM \\
\hline 2 & 6.268 & 1314 & 1336 & 91 & glyceric acid* & 73 (BP), 147, 189, 103, 292 & $\mathrm{SgM}, \mathrm{SsM}$ \\
\hline 3 & 8.615 & 1397 & 1404 & 92 & pentanedioic acid* & 147 (BP), 73, 261, 158 & SsE \\
\hline 4 & 8.989 & 1420 & 1420 & 93 & $\beta$-caryophyllene & 69 (BP), 93, 133, 79, 91 & $\mathrm{SgM}, \mathrm{SmM}$ \\
\hline 5 & 10.980 & 1482 & 1499 & 96 & malic acid* & 73 (BP), 147, 233 & $\mathrm{SgM}, \mathrm{SmH}, \mathrm{SmM}$ \\
\hline 6 & 11.731 & 1511 & 1521 & 96 & pyroglutamic acid* & 156 (BP), 73, 147 & $\mathrm{SgM}, \mathrm{SmM}, \mathrm{SsM}$ \\
\hline 7 & 14.946 & 1600 & 1613 & 82 & $\begin{array}{c}\text { 3-hydroxy-3-methylglutaric } \\
\text { acid* }\end{array}$ & 73 (BP), 103, 147, 219, 247 & $\mathrm{SsE}, \mathrm{SgE}$ \\
\hline 8 & 21.879 & 1815 & 1828 & 90 & benzoic acid, 3,4-dihydroxy* & 73 (BP), 193, 370, 355, 311 & $\mathrm{SgM}$ \\
\hline 9 & 21.987 & 1818 & 1838 & 92 & citric acid $*$ & 73 (BP), 193, 370, 355, 311 & $\mathrm{SgM}$ \\
\hline 10 & 22.788 & 1837 & 1837 & 94 & neophytadiene & $\begin{array}{c}66(\mathrm{BP}), 95,82,57,123 \\
278\left[\mathrm{M}^{+}\right]^{\mathrm{h}}\end{array}$ & $\mathrm{SgE}, \mathrm{SgM}, \mathrm{StE}, \mathrm{StM}$ \\
\hline 11 & 27.789 & 1990 & 1992 & 91 & galactonic acid* & 73 (BP), 147, 292, 319, 217 & SsE, SsM, StM \\
\hline 12 & 27.963 & 1994 & 1997 & 92 & gluconic acid* & 73 (BP), 147, 333, 292, 217 & $\mathrm{SgH}, \mathrm{SgM}, \mathrm{SsH}, \mathrm{SsE}, \mathrm{StH}, \mathrm{StM}$ \\
\hline 13 & 29.571 & 2046 & 2047 & 97 & hexadecanoic acid* & $\begin{array}{c}117 \text { (BP), } 73,313,132,145 \\
328\left[\mathrm{M}^{+*}\right]\end{array}$ & $\begin{array}{c}\mathrm{SgH}, \mathrm{SgE}, \mathrm{SgM}, \mathrm{SmH}, \mathrm{SmE} \\
\mathrm{SmM} \text {, SsH, SsM, SsE, StE, StM }\end{array}$ \\
\hline 14 & 31.199 & 2094 & 2092 & 93 & linolenic acid methyl ester & 79 (BP), 67, 95, 93, 108 & $\mathrm{SsH}, \mathrm{SgH}$ \\
\hline 15 & 33.242 & 2162 & 2164 & 93 & linolenic acid ethyl ester & 79 (BP), 67, 95, 93, 108 & $\mathrm{StE}$ \\
\hline 16 & 33.393 & 2172 & 2183 & 94 & phytol* & 143 (BP), 73, 75, 123 & $\begin{array}{c}\mathrm{SgH}, \mathrm{SmH}, \mathrm{SsH}, \mathrm{SsE}, \mathrm{SsM} \\
\text { StH, StM }\end{array}$ \\
\hline 17 & 34.403 & 2207 & 2212 & 97 & linoleic acid* & $\begin{array}{c}73(\mathrm{BP}), 75,81,337,95 \\
352\left[\mathrm{M}^{+*}\right]\end{array}$ & $\begin{array}{l}\mathrm{SgH}, \mathrm{SgE}, \mathrm{SgM}, \mathrm{SmH}, \mathrm{SmE} \text {, } \\
\mathrm{SsH}, \mathrm{SsE}, \mathrm{SsM}, \mathrm{StH}, \mathrm{StE}, \mathrm{StM}\end{array}$ \\
\hline 18 & 34.574 & 2212 & 2218 & 96 & $\alpha$-linolenic acid* & $\begin{array}{c}75 \text { (BP), } 73,95,108,129,335, \\
350\left[\mathrm{M}^{+*}\right]\end{array}$ & $\begin{array}{c}\mathrm{SgH}, \mathrm{SgE}, \mathrm{SgM}, \mathrm{SmH}, \mathrm{SmE} \\
\text { SsH, SsE, SsM, StH, StE, StM }\end{array}$ \\
\hline 19 & 35.459 & 2243 & 2248 & 96 & stearic acid* & $\begin{array}{c}117(\mathrm{BP}), 73,341,132,129 \\
356\left[\mathrm{M}^{+*}\right]\end{array}$ & $\begin{array}{c}\mathrm{SgH}, \mathrm{SgE}, \mathrm{SgM}, \mathrm{SmH}, \mathrm{SmE} \\
\mathrm{SsH}, \mathrm{SsE}, \mathrm{SsM}, \mathrm{StH}, \mathrm{StE}, \mathrm{StM}\end{array}$ \\
\hline 20 & 40.831 & 2441 & 2447 & 92 & eicosanoic acid* & $\begin{array}{c}117(\mathrm{BP}), 73,369,132,145 \\
384\left(\mathrm{M}^{+}\right)\end{array}$ & $\mathrm{SgH}, \mathrm{SmH}, \mathrm{StH}, \mathrm{StM}$ \\
\hline 21 & 45.898 & 2639 & 2638 & 92 & docosanoic acid* & $\begin{array}{c}117 \text { (BP), } 73,397,132,145 \\
412\left[\mathrm{M}^{+*}\right]\end{array}$ & $\mathrm{SgH}, \mathrm{SmH}, \mathrm{SsH}, \mathrm{StM}$ \\
\hline 22 & 46.710 & 2663 & 2705 & 73 & chrysin* or isomer & 383 (BP), 384,73 & $\mathrm{SmE}$ \\
\hline 23 & 49.998 & 2807 & 2812 & 98 & squalene & $\begin{array}{c}69 \text { (BP), } 81,121,137 \\
410\left[\mathrm{M}^{+*}\right]\end{array}$ & $\begin{array}{c}\mathrm{SgH}, \mathrm{SgE}, \mathrm{SmH}, \mathrm{SsH}, \mathrm{SsE} \\
\text { StH, StE, StM }\end{array}$ \\
\hline 24 & 50.716 & 2837 & 2836 & 90 & tetracosanoic acid* & $\begin{array}{c}117 \text { (BP), } 73,425,132,145 \\
440\left[\mathrm{M}^{+*}\right]\end{array}$ & $\mathrm{SgH}, \mathrm{SgE}, \mathrm{SsH}, \mathrm{SsE}, \mathrm{StE}, \mathrm{StM}$ \\
\hline 25 & 53.176 & 2939 & 2943 & 75 & trans-catechine* or isomer & 368 (BP), 73, 283, 578 & $\mathrm{SmE}$ \\
\hline 26 & 54.152 & 2983 & 3004 & 76 & $\beta$-tocoferol* & $488\left(\mathrm{BP}\right.$ and $\left.\left[\mathrm{M}^{+*}\right]\right), 223,73$ & $\mathrm{SmH}$ \\
\hline 27 & 56.925 & 3120 & 3149 & 76 & $\alpha$-tocopherol* & $542\left(\mathrm{BP}\right.$ and $\left.\left[\mathrm{M}^{+*}\right]\right), 237,73$ & $\begin{array}{c}\mathrm{SgH}, \mathrm{SgE}, \mathrm{SmH}, \mathrm{SsH}, \mathrm{SsE}, \\
\text { StE, StM }\end{array}$ \\
\hline 28 & 57.501 & 3164 & 3171 & 87 & quercetin* & 575 (BP), 73, 497 & $\mathrm{SgH}, \mathrm{SmH}, \mathrm{SsH}, \mathrm{StH}, \mathrm{StM}$ \\
\hline 29 & 59.460 & 3242 & 3262 & 90 & stigmasterol* & $\begin{array}{c}83(\mathrm{BP}), 129,255,394 \\
484\left[\mathrm{M}^{+*}\right]\end{array}$ & $\begin{array}{c}\mathrm{SgH}, \mathrm{SgE}, \mathrm{SmH}, \mathrm{SmM}, \mathrm{SsH} \\
\text { SsE, StH, StE, StM }\end{array}$ \\
\hline 30 & 60.668 & 3302 & 3296 & 90 & $\beta$-sitosterol* & 129 (BP), 357, 396, $486\left[\mathrm{M}^{+*}\right]$ & $\begin{array}{c}\mathrm{SgH}, \mathrm{SgE}, \mathrm{SgM}, \mathrm{SmH}, \mathrm{SmE} \\
\mathrm{SmM}, \mathrm{SsH}, \mathrm{SsE}, \mathrm{SsM}, \mathrm{StH} \\
\text { StE, StM }\end{array}$ \\
\hline 31 & 60.895 & 3314 & 3312 & 86 & $\beta$-amyrin* & $218(\mathrm{BP}), 203,498\left[\mathrm{M}^{+\bullet}\right]$ & SmH, SsH, SsE, SsM, StH \\
\hline 32 & 61.418 & 3340 & 3334 & 96 & 1-triacontanol* & 495 (BP), 75, 97 & $\begin{array}{c}\mathrm{SgH}, \mathrm{SgE}, \mathrm{SgM}, \mathrm{SmH}, \mathrm{SmE} \\
\mathrm{SsH}, \mathrm{SsE}, \mathrm{SsM}, \mathrm{StH}, \mathrm{StM}\end{array}$ \\
\hline 33 & 61.885 & 3355 & 3354 & 82 & $\alpha$-amyrin* & $218(\mathrm{BP}), 189,498\left[\mathrm{M}^{+\bullet}\right]$ & $\mathrm{SmH}, \mathrm{SsH}$ \\
\hline 34 & 63.136 & 3434 & 3445 & - & triacontanoic acid* & $\begin{array}{c}117(\mathrm{BP}), 73,145,509, \\
524\left[\mathrm{M}^{+\bullet}\right]\end{array}$ & $\mathrm{StH}, \mathrm{StM}$ \\
\hline
\end{tabular}

${ }^{\mathrm{a}} \mathrm{Rt}=$ retention time; ${ }^{\mathrm{b}} \mathrm{RI}_{\text {exp }}=$ experimental retention index; ${ }^{\mathrm{C}} \mathrm{RI}_{\mathrm{lit}}=$ retention index from literature; ${ }^{\mathrm{d}}$ similarity based on NIST MS database; ${ }^{\mathrm{e}}$ representative ions in decreasing order of abundance; ${ }^{\mathrm{f}}$ Senna $\mathrm{ssp} .: \mathrm{SgH}=$ S. gardneri hexane, $\mathrm{SgE}=$ S. gardneri ether, $\mathrm{SgM}=$ S. gardneri methanol, $\mathrm{SmH}=$ S. macranthera hexane, $\mathrm{SmE}=$ Senna macranthera ether, $\mathrm{SmM}=$ S. macranthera methanol, $\mathrm{SsH}=$ S. splendida hexane, $\mathrm{SsE}=$ S. splendida ether, $\mathrm{SsM}=$ S. splendida methanol, $\mathrm{StH}=S$. trachypus hexane, $\mathrm{StE}=$ S. trachypus ether, $\mathrm{StM}=$ S. trachypus methanol; ${ }^{\mathrm{B}} \mathrm{BP}=$ base peak; ${ }^{\mathrm{h}}\left[\mathrm{M}^{+} \cdot\right]=$ molecular ion; ${ }^{*}$ compounds identified as TMS derivatives. 


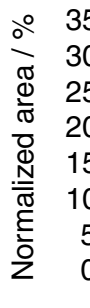

35

(a)

(a)

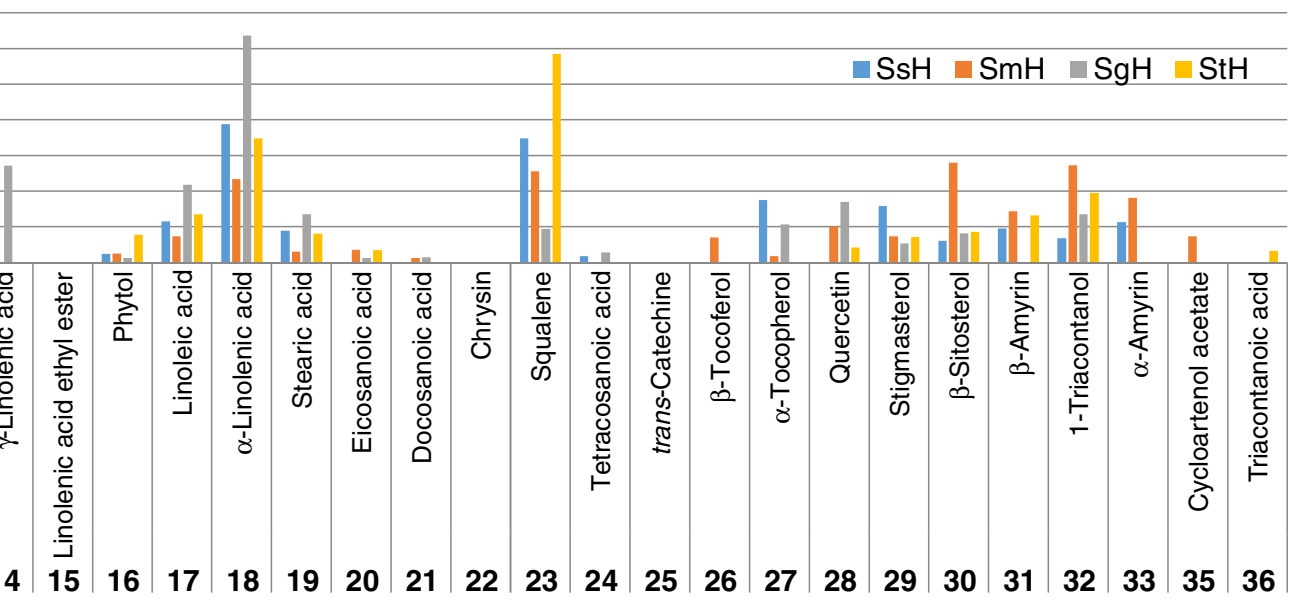

\begin{tabular}{l|l|l|l|l|l|l|l|l|l|l|l|l|l|}
5 & 12 & 13 & 14 & 15 & 16 & 17 & 18 & 19 & 20 & 21 & 22 & 23 & 24 \\
\hline
\end{tabular}
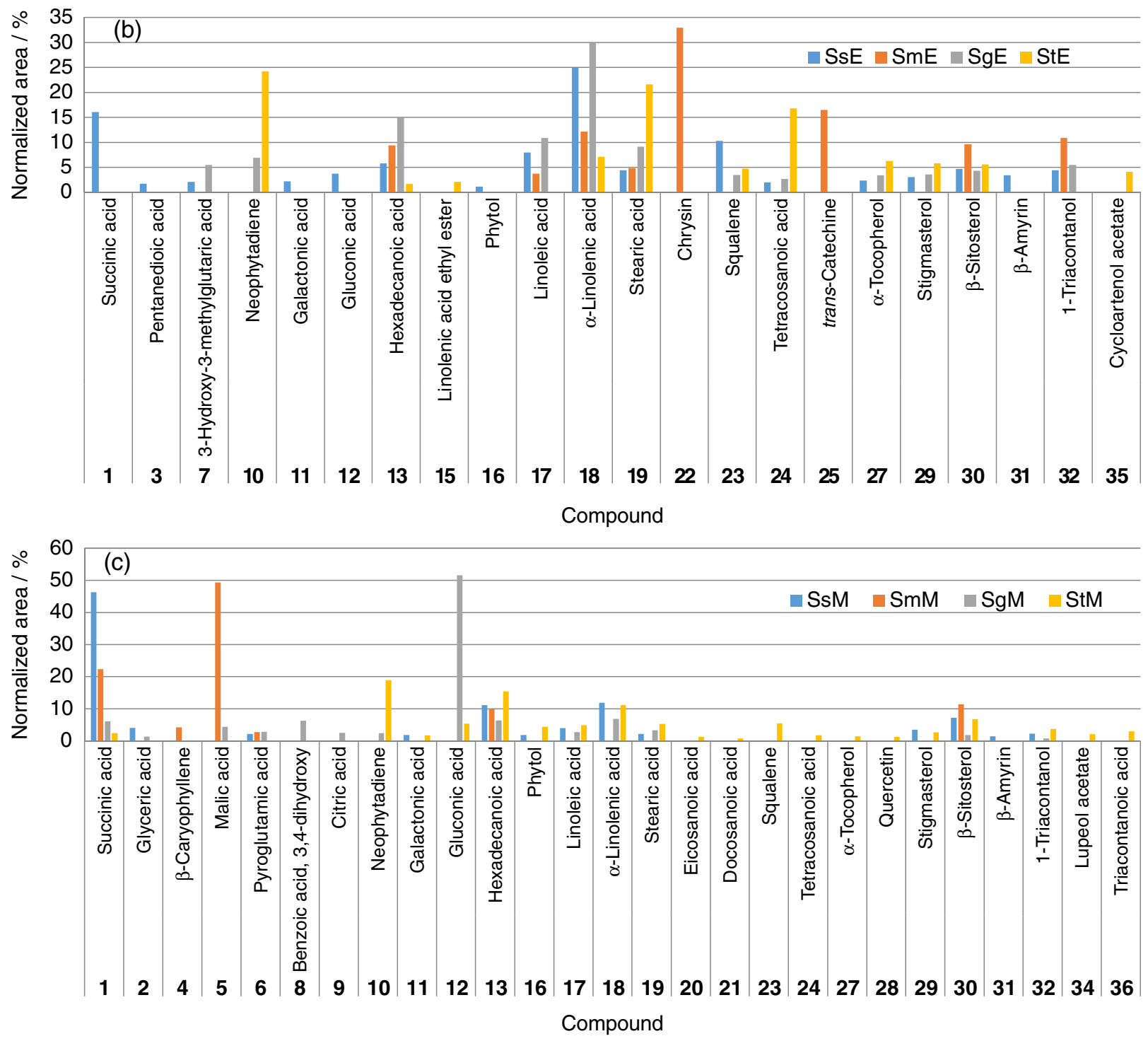

Figure 1. Chemical profiles of Senna spp. leaves extracted with (a) hexane; (b) ethyl ether; and (c) methanol. Compounds are shown with more than $1 \%$ of the normalized area for each extract. $\mathrm{SgH}=S$. gardneri hexane, $\mathrm{SgE}=$ S. gardneri ether, $\mathrm{SgM}=S$. gardneri methanol, SmH $=S$. macranthera hexane, $\mathrm{SmE}=$ Senna macranthera ether, $\mathrm{SmM}=S$. macranthera methanol, $\mathrm{SsH}=S$. splendida hexane, SsE $=S$. splendida ether, $\mathrm{SsM}=S$. splendida methanol, $\mathrm{StH}=S$. trachypus hexane, $\mathrm{StE}=S$. trachypus ether, $\mathrm{StM}=$ S. trachypus methanol extract. 

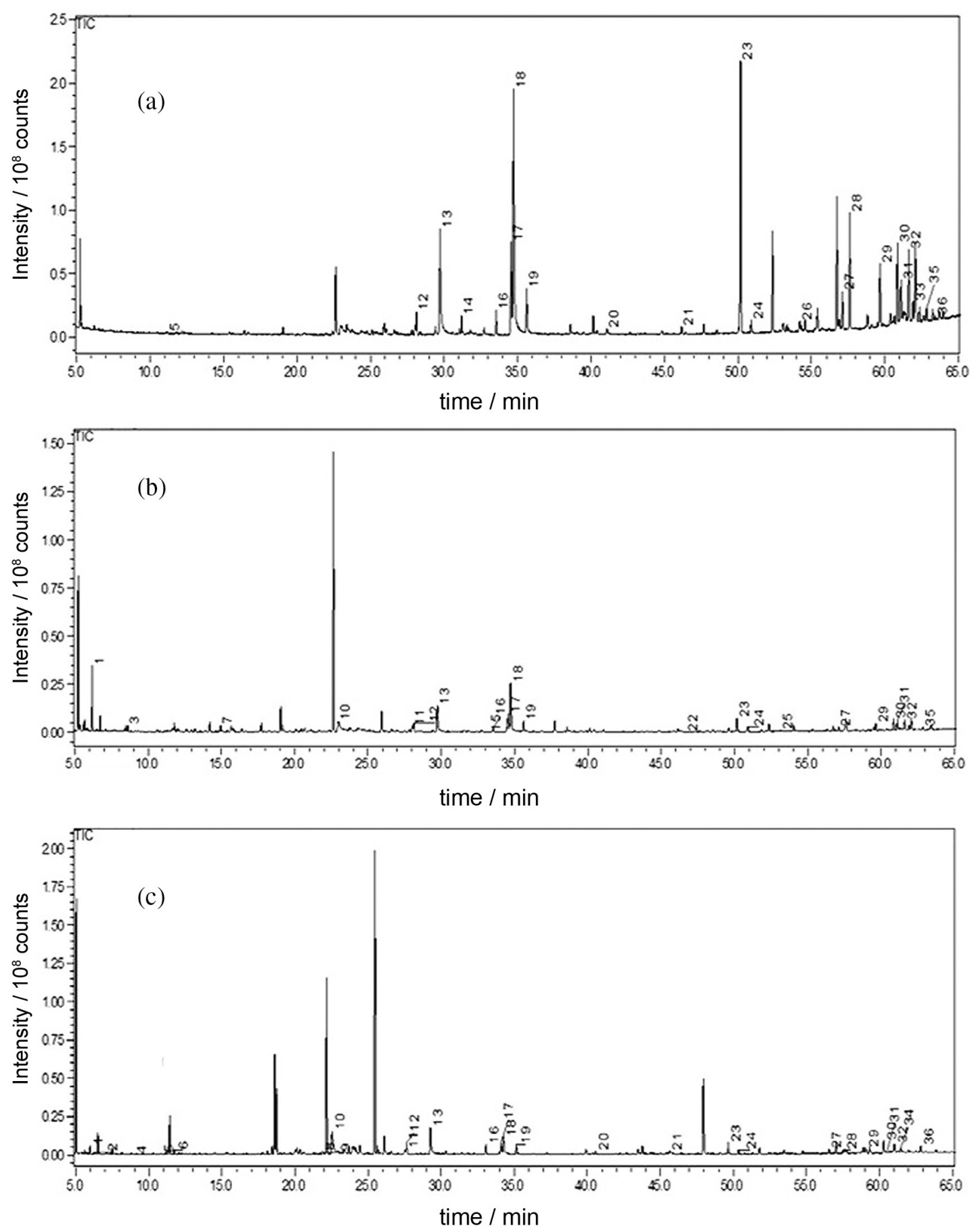

Figure 2. Representative GC-MS chromatograms from (a) hexane extract of leaves from Senna splendida; (b) ethyl ether extract of leaves from Senna splendida; and (c) methanol extract of leaves from Senna trachypus.

variances of the data, with the residual Q and Hotelling's $\mathrm{T} 2$ showing only one sample ( $\mathrm{SgM}$ ) outside the $95 \%$ confidence intervals. The best adjustments were obtained in the score (Figure $4 \mathrm{a}$ ) and the loading (Figure $4 \mathrm{~b}$ ) plots of LV4 $\times$ LV2 in which the cytotoxic extracts from cluster A ( $\mathrm{SgH}$ and $\mathrm{SsE}$ ) were in the identical quadrant (Figure 4a) as variable 53 (Figure $4 \mathrm{~b}$ ), which could be related to the cytotoxicity of these extracts. Variable 53 corresponded to compound 18, identified as $\alpha$-linolenic acid (ALA). Several studies examined linoleic acid in combination with other compounds in evaluations of anticancer activity. ${ }^{25,26}$

Dai $^{27}$ and Sun et al. ${ }^{28}$ reported that polyunsaturated fatty acids have inhibitory effects on several tumor cell lines by inducing apoptosis, which corroborates the results obtained with PLS in this study. The $\omega-3$ fatty acids are cytotoxic because of selective anticancer effects through 
Table 2. Cytotoxic activity of Senna spp. extracts on human cancer cell lines (\% inhibition $\pm \mathrm{SD}^{\mathrm{a}}$ )

\begin{tabular}{|c|c|c|c|}
\hline Sample & $\mathrm{HTC}-116^{\mathrm{c}}$ & SF-295 & OVCAR-8 ${ }^{\mathrm{e}}$ \\
\hline $\mathrm{SgH}$ & $59.75 \pm 0.60$ & $52.85 \pm 5.21$ & $24.61 \pm 13.82$ \\
\hline $\operatorname{SgE}$ & $11.63 \pm 2.53$ & $24.29 \pm 6.13$ & $0.01 \pm 0.00$ \\
\hline $\mathrm{SgM}$ & $6.56 \pm 10.65$ & $5.77 \pm 2.80$ & $0.01 \pm 0.00$ \\
\hline $\mathrm{SmH}$ & $28.27 \pm 3.05$ & $39.27 \pm 7.14$ & $0.01 \pm 0.01$ \\
\hline SmE & $5.59 \pm 6.05$ & $20.54 \pm 6.22$ & $0.01 \pm 0.00$ \\
\hline SmM & $1.37 \pm 3.82$ & $18.56 \pm 5.55$ & $44.64 \pm 0.99$ \\
\hline $\mathrm{SsH}$ & $13.85 \pm 1.29$ & $36.92 \pm 0.14$ & $10.43 \pm 41.62$ \\
\hline SsE & $31.37 \pm 6.65$ & $48.28 \pm 10.04$ & $21.92 \pm 1.67$ \\
\hline SsM & $19.65 \pm 5.28$ & $28.66 \pm 11.53$ & $0.01 \pm 0.00$ \\
\hline $\mathrm{StH}$ & $27.39 \pm 3.52$ & $21.19 \pm 3.96$ & $0.01 \pm 0.00$ \\
\hline StE & $20.19 \pm 1.67$ & $37.12 \pm 5.65$ & $9.41 \pm 45.94$ \\
\hline StM & $7.23 \pm 1.29$ & $32.38 \pm 2.32$ & $35.4 \pm 23.31$ \\
\hline DOX, $\mathrm{IC}_{50}\left[\mu \mathrm{mol} \mathrm{L}{ }^{-1}\right]^{\mathrm{f}}$ & $0.12(0.09-0.17)$ & $0.22(0.16-0.24)$ & $0.34(0.31-0.36)$ \\
\hline
\end{tabular}

${ }^{a} \mathrm{SD}=$ standard deviation; ${ }^{\mathrm{b}}$ sample: $\mathrm{SgH}=S$. gardneri hexane, $\mathrm{SgE}=S$. gardneri ether, $\mathrm{SgM}=$ S. gardneri methanol, $\mathrm{SmH}=S$. macranthera hexane, $\mathrm{SmE}=$ Senna macranthera ether, $\mathrm{SmM}=$ S. macranthera methanol, $\mathrm{SsH}=S$. splendida hexane, $\mathrm{SsE}=$ S. splendida ether, SsM $=S$. splendida methanol, $\mathrm{StH}=S$. trachypus hexane, $\mathrm{StE}=S$. trachypus ether, $\mathrm{StM}=$ S. trachypus methanol; ${ }^{\mathrm{c} H T C}-116=$ human colon; ${ }^{\mathrm{d} O V A C A R}-8=$ ovarian carcinoma; ${ }^{\mathrm{e}} \mathrm{SF}-295$ = human glioblastoma; ${ }^{\mathrm{f}} \mathrm{DOX}=$ doxorubicin was the positive control. $\mathrm{IC}_{50}$ is the drug concentration that caused 50\% inhibition of cell growth, with the corresponding $95 \%$ confidence interval (CI 95\%) shown below.

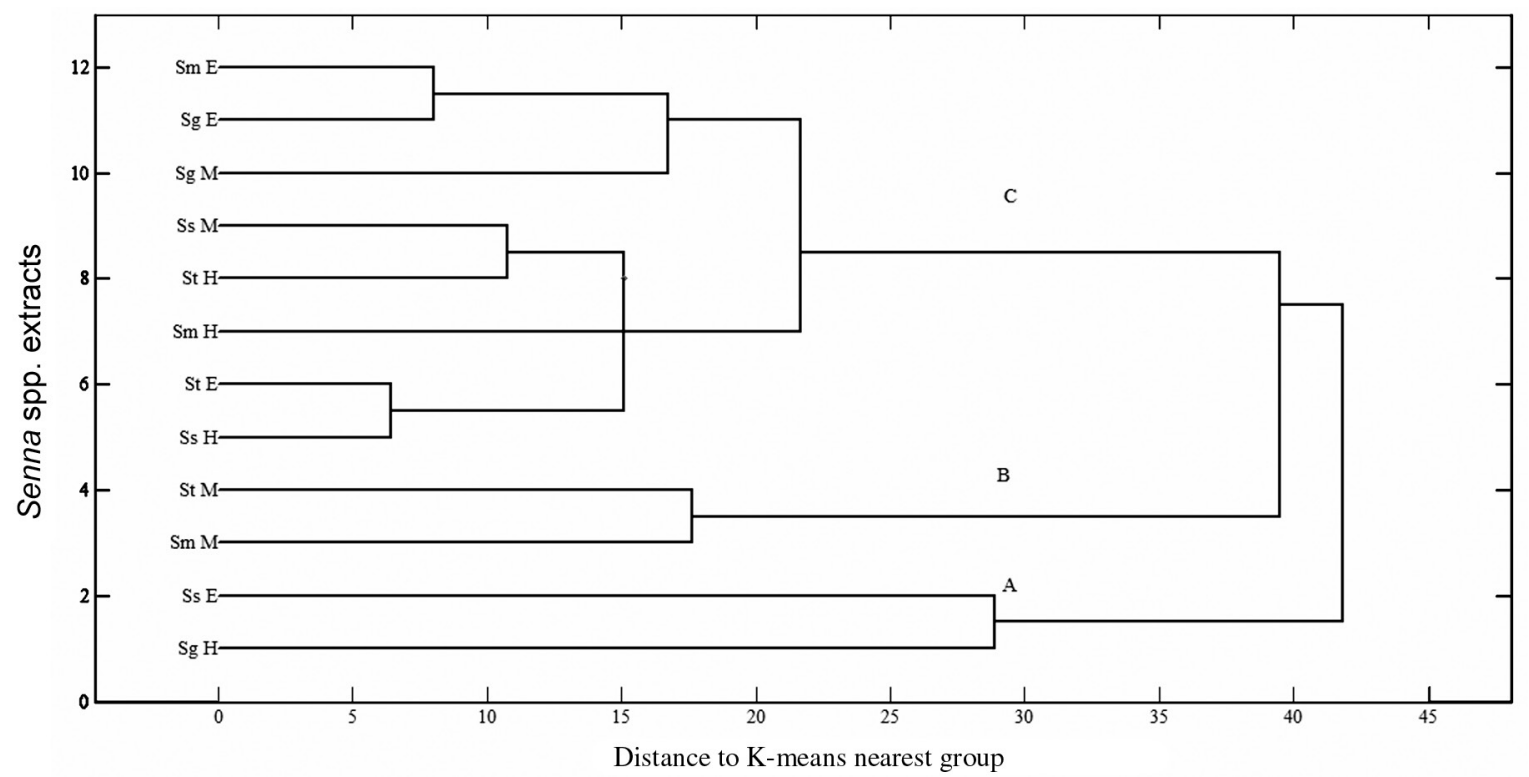

Figure 3. Dendrogram of HCA of the extracts from leaves of Senna spp. Cluster A = 2 samples (cytotoxic to HCT-116 and SF-295 cell lines); cluster B $=2$ samples (cytotoxic to OVCAR-8 cell line); and cluster C $=8$ samples (low and no cytotoxicity).

the generation of free radicals and lipid peroxidation. ${ }^{29}$ Dai et $a l . .^{30}$ showed that polyunsaturated fatty acids are cytotoxic to tumor cells, and of the fatty acids tested, linoleic acid (LA) and $\alpha$-linolenic acid (ALA) were the most effective in suppressing the growth of normal gastric cells (GES1) at 180 and $200 \mu \mathrm{mol} \mathrm{L}^{-1}$ and those of gastric carcinoma (MGC and SGC) at $200 \mu \mathrm{mol} \mathrm{L}^{-1}$. The induction of apoptosis by $\alpha$-linolenic acid (18) (ALA) was observed by Vecchini et al. ${ }^{31}$ and Scheim ${ }^{32}$ and likely occurred because of the reduction of nitric oxide, as proposed by Deshpande et al. ${ }^{33}$ In recent studies with mouse models,
ALA (18) reduced breast tumor growth while increasing the efficacy of chemotherapeutic agents. However, these studies did not confirm whether the effects were caused by ALA or its metabolites..$^{34}$ No compound was correlated with the cytotoxicity of the samples in cluster B, which included two methanolic extracts, most likely because several of the polar compounds in these extracts did not elute in the chromatographic conditions used in this study.

Additionally, some compounds were detected in only one species; for example, the flavonoid, chrysin (22), was identified only in S. macranthera, and the flavonoid, 

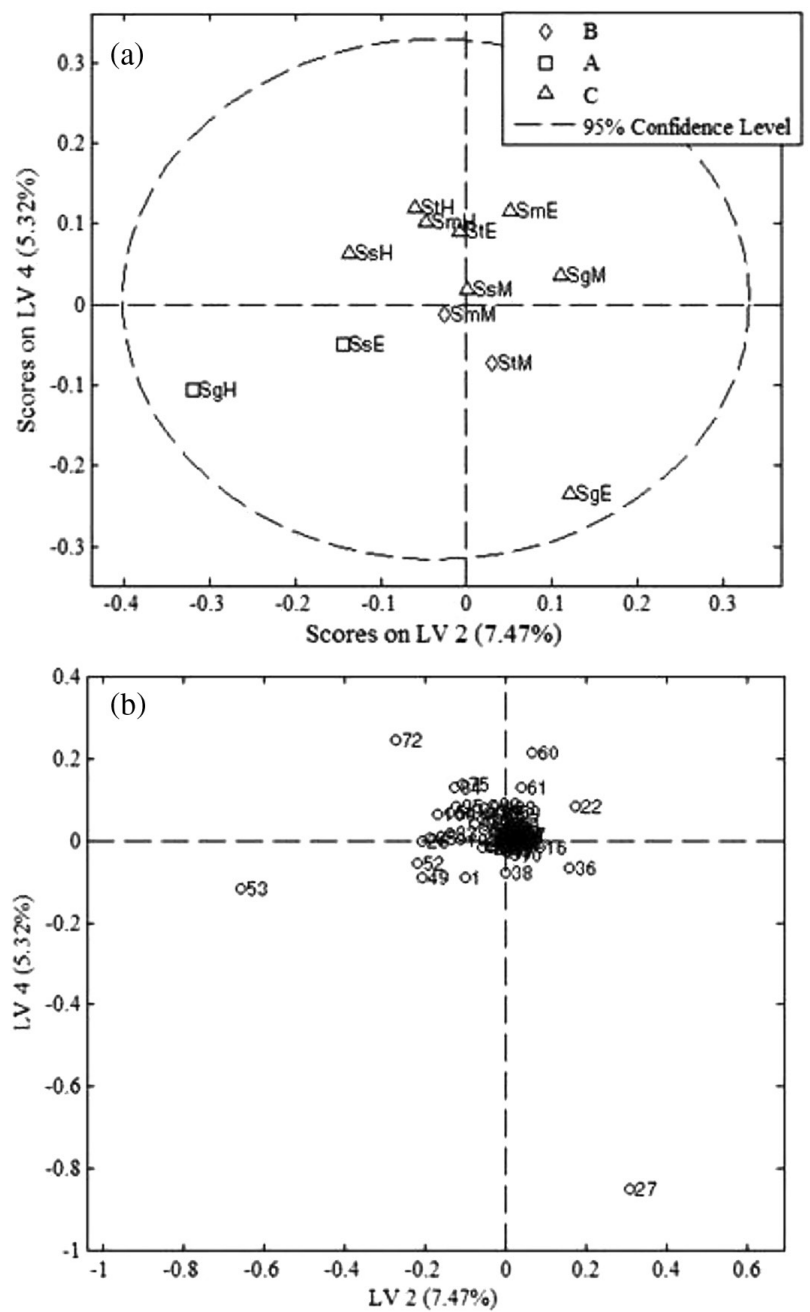

Figure 4. Score (a) and loading (b) plots obtained after PLS-DA using 12 extracts from Senna spp. and 110 compound areas $(12 \times 110)$. A) extracts cytotoxic to HTC-116 and SF-295 cells; B) extracts cytotoxic to OVCAR-8 cells; and C) extracts with low or no cytotoxicity.

quercetin (28), was identified only in the methanolic extract of S. trachypus. These compounds have shown excellent potential for chemopreventive and cancer therapy ${ }^{35}$ and have anti-inflammatory and antioxidant activities. ${ }^{36}$ However, eleven compounds were identified in all the extracts that are typically encountered in different families and genera of higher plants. For example, all extracts contained the triterpene squalene (23). This compound, which is produced by all higher organisms and has beneficial effects on human health and antioxidant activity, has also been isolated from the leaves and roots of Ramonda serbica and R. nathaliae, ${ }^{37}$ and from the marine diatom Pleurosigma strigosum. ${ }^{38}$ The triterpenes $\alpha$-amyrin (33) and $\beta$-amyrin (31) were detected only in the $n$-hexane extracts of leaves of $S$. macranthera and $S$. splendida. These compounds, with anti-inflammatory, anti-conceptive, and hepatoprotective pharmacological activities, have also been isolated as a mixture from different natural sources, including other species of the genus Senna, i.e., $S$. spectabilis var. excelsa and $S$. reticulata. ${ }^{7}$ The steroids $\beta$-sitosterol (30) and stigmasterol (29) are common compounds in species of several genera and families, and the properties of $\beta$-sitosterol isolated from S. spectabilis var. excelsa have been reported as antibacterial, antiinflammatory and analgesic. ${ }^{6}$

\section{Conclusions}

The GC-MS analyses of 12 extracts from the leaves of four species of Senna identified 34 compounds in different groups that included fatty acids, steroids, triterpenes and flavonoids not reported previously for these species. The use of multivariate analyses (HCA and PLS-DA) led us to infer that the cytotoxicity of some Senna extracts to HTC-116 and SF-295 tumor cells lines was attributed to linolenic acid, an inference that was reinforced by literature data. Moreover, with analytical techniques, dereplication and multivariate statistical analysis, this study demonstrated that it was possible to effectively identify hit compounds and by avoiding the steps of extract fractionation and purification of known compounds, to improve the research approach in the prospect for new drug prototypes from biological sources.

\section{Supplementary Information}

Supplementary data (MS spectra) are available free of charge at http://jbcs.sbq.org.br.

\section{Acknowledgments}

The authors are very thankful to the Federal University of Ceará (UFC), State University Paulista (UNESP), Prof Norberto Peporine Lopes and Izabel Cristina Casanova Turatti from the University of São Paulo (USP) for their support with the GC-MS analyses, to Prof Fernando Batista Costa from the University of São Paulo (USP) for accurate comments and to FAPESP, CNPq and CAPES for all the financial support.

\section{References}

1. Irwin, H. S.; Barneby, R. C.; The American Cassiinae: a Synoptical Revision of Leguminoseae Tribe Cassia Subtribe Cassinae in the New World, New York Bot. Gard: New York, USA, 1982.

2. Rodrigues, R. S.; Flores, A. S.; Miotto, T. S.; Baptista, L. R. S. R.; Acta Bot. Bras. 2005, 19, 1.

3. Dantas, M. M.; Silva, M. J.; Hoehnea 2013, 40, 99. 
4. Rahman, M. O.; Rahman, M. D. Z.; Begun, A.; Bangladesh J. Plant Taxon. (Online) 2013, 20, 77.

5. Irwin, H. S.; Barneby, R. C. In Advances in Legume Systematics; Polhill, R. M.; Raven, P. H., eds.; Kew: The Royal Botanic Gardens: London, UK, 1981, ch. 1.

6. Silva, F. O.; Oliveira, I. R.; Silva, M. G. V.; Braz-Filho, R.; Quim. Nova 2010, 33, 1874.

7. Santos, R. N.; Silva, M. G. V.; Quim. Nova 2008, 31, 1979.

8. Melo, G. M. A.; Silva, M. C. R.; Guimarães, T. P.; Pinheiro, K. M.; Matta, C. B. B. Q.; Pivatto, M.; Bolzani, V. S.; AlexandreMoreira, M. S.; Viegas Jr., C.; Phytomedicine 2013, 3, 277.

9. Hardcastle, J. D.; Wilkins, J. L.; Gut 1970, 11, 1038.

10. Guarize, L.; Costa, J. C.; Dutra, L. B.; Mendes, R. F.; Lima, I. V. A.; Scio, E.; Nat. Prod. Res. 2012, 26, 331.

11. Villaseñor, I. M.; Sanchez, A. C.; Z. Naturforsch. 2009, 64, 335.

12. Yeung-Beom, P.; Seon-Bong, K.; J. Microbiol. Biotechnol. 2011, 21, 1043.

13. Rahman, M. A.; Sultana, R.; Emran, T. B.; Islan, M. S.; Rahman, M. A.; Chakma, S. C.; Rashid, H.; Hasan, C. M. M.; BMC Complementary Altern. Med. 2013, 13, 25.

14. Wongtongtair, S.; Chanvorachote, P.; Hutamekalin, P.; Chaichantipyuth, C.; Lipipun, V.; Tiensiwakul, P.; Meksuriyen, D.; J. Ethnopharmacol. 2011, 137, 971.

15. Nsonde-Ntandou, G. F.; Banzouzib, J. T.; Mbatchia, B.; Elion-Itoua, R. D. G.; Etou-Ossibia, A. W.; Ramosd, S.; Benoit-Vicale, F.; Abenaa, A. A.; Ouambah, J. M.; J. Ethnopharmacol. 2010, 127, 108.

16. Esakkirajan, M.; Prabhu, N. M.; Arulvasu, C.; Beulaja, M.; Manikandan, R.; Thiagarajan, R.; Govindaraju, K.; Prabhu, D.; Dinesh, D.; Babu, G.; Dhanasekaran, G.; Spectrochim. Acta, Part A 2014, 120, 462.

17. Funari, C. S.; Castro-Gamboa, I.; Cavalheiro, A. J.; Bolzani, V. S.; Quim. Nova 2013, 10, 1605.

18. Rochfort, S.; J. Nat. Prod. 2005, 68, 1813.

19. Kanani, H.; J. Chromatogr. B: Anal. Technol. Biomed. Life Sci. 2008, 87, 191.

20. Madsen, R.; Lundstedt, T.; Trygg, J.; Anal. Chim. Acta 2010 , $659,23$.
21. Chagas-Paula, D. A.; Zhang, T.; Costa, F. B.; Edrada-Ebel, R.; Metabolites 2015, 5, 404.

22. Isidorov, V. A.; Szczepaniak, L.; J. Chromatogr. A 2009, 1216, 8998.

23. Mossman, T.; J. Immunol. Methods 1983, 65, 55.

24. Van den Dool, H.; Kratz, P. D.; J. Chromatogr. A 1963, 11, 463.

25. Tao, X. M.; Wang, J. C.; Wang, J. B.; Feng, Q.; Gao, S. Y.; Zhang, L. R.; Zhang, Q.; Eur. J. Pharm. Biopharm. 2012, 82, 406.

26. Roz, E.; Bard, J. M.; Huvelin, J. M.; Nazih, H.; Prostaglandins, Leukotrienes Essent. Fatty Acids 2013, 88, 267.

27. Dai, U. N.; Med. Sci. Monit. 2002, 8, RA79.

28. Sun, Z.; Wang, H.; Ye, S.; Xiao, S.; Liu, J.; Wang, W.; Jiang, D.; Liu, X.; Wang, J.; Prostaglandins Other Lipid Mediators 2012, 99, 1.

29. Menédez, J. A.; Vázquez-Martín, A.; Ropero, S.; Colomer, R.; Lupu, R.; Trueta, J.; Clin. Transl. Oncol. 2006, 8, 812.

30. Dai, J.; Shen, J.; Pan, W.; Shen, S.; Das, U. N.; Lipids Health Dis. 2013, 12, 71.

31. Vecchini, A.; Ceccarelli, V.; Susta, F.; Caligiana, P.; Orvietani, P.; Binaglia, L.; Nocentini, G.; Ricardi, C.; Calviello, G.; Palozza, P.; Maggiano, N.; Di Nardo, P.; J. Lipid Res. 2004, 45, 308.

32. Scheim, D. E.; Lipids Health Dis. 2009, 8, 54.

33. Deshpande, R.; Mansara, P.; Suryavanshi, S.; Kaul-Ghanekar, R.; J. Mol. Biochem. 2013, 2, 6.

34. Mason, J. K.; Klaire, S.; Kharotia, S.; Wiggins, A. K. A.; Thompson, L. U.; Lipids Health Dis. 2015, 14, 90.

35. Kasala, E. R.; Bodduluru, L. N.; Madana, R. M.; V, A. K.; Gogoi, R.; Barua, C. C.; Toxicol. Lett. 2015, 4, 214.

36. Joshi, U. J.; Gadge, A. S.; D’Mello, P.; Sinha, R.; Srivastava, S.; Govi, G.; J. Pharm. Pharm. Sci. 2011, 2, 1756.

37. Radulović, N. S.; Blagojević, P. D.; Palić, R. W.; Zlatković, B. K.; Stevanović, B. M.; J. Serb. Chem. Soc. 2009, 74, 35.

38. Grossi, V.; Beker, B.; Geenevasen, J. A. J.; Schouten, S.; Raphel, D.; Fontaine, M.; Damtsé, J. S. S.; Phytochemistry 2004, 65, 3049.

Submitted: November 4, 2015

Published online: March 14, 2016

FAPESP has sponsored the publication of this article. 